\title{
Impact of Terminalia arjuna (Roxb.) Leaf Litter and Hosted Tasar Silkworm Excreta on Quality of Paddy and Soil Properties
}

\author{
R.J. Mevada ${ }^{1}$, Dileswar Nayak ${ }^{2 *}$ and D.P. Patel ${ }^{2}$ \\ ${ }^{1}$ Department of Silviculture and Agroforestry, ${ }^{2}$ Department of Natural Resource Management, \\ ASPEE College of Horticulture and Forestry, Navsari Agricultural University, \\ Navsari - 396 450, Gujarat, India \\ *Corresponding author
}

A B S T R A C T

An experiment was carried out to study the impact of Terminalia arjuna (Roxb.) leaf litter and hosted tasar silkworm excreta on quality of paddy and soil porosities $c v$. GNR 4 and

\begin{tabular}{|c|}
\hline Keywords \\
\hline $\begin{array}{l}\text { Tasar silkworm excreta, } \\
\text { Leaf litter, Chemical } \\
\text { fertilizer, Soil properties, } \\
\text { Terminalia arjuna, Paddy }\end{array}$ \\
\hline Article Info \\
\hline $\begin{array}{l}\text { Accepted: } \\
30 \text { April } 2018 \\
\text { Available Online: } \\
10 \text { May } 2018\end{array}$ \\
\hline
\end{tabular}
laid out in nine treatments with Completely Randomized Design. The study revealed that the protein content of grain and nitrogen content of grain, straw recorded statistically higher with the application of 50\% RDN through inorganic fertilizer $+50 \%$ RDN from arjuna hosted tasar silkworm excreta. However, protein yield and nitrogen uptake by grain and straw were recorded higher with the $75 \%$ RDN through inorganic fertilizer $+25 \%$ RDN from arjuna hosted tasar silkworm excreta. Further, it showed that the available nitrogen was found higher in $75 \% \mathrm{RDN}$ through inorganic fertilizer $+25 \%$ RDN from arjuna hosted tasar silkworm excreta. Whereas, $\mathrm{P}_{2} \mathrm{O}_{5}$ were recorded higher under $100 \%$ RDN from arjuna hosted tasar silkworm excreta. Soil organic carbon and $\mathrm{K}_{2} \mathrm{O}$ were recorded significantly maximum under the $100 \%$ RDN from leaf litter. Furthermore, soil bulk density and $\mathrm{pH}$ reduced, while porosity increases in $100 \% \mathrm{RDN}$ from leaf litter. The quality of the paddy was improved under 50\% RDN through inorganic fertilizer $+50 \%$ RDN from arjuna hosted tasar silkworm excreta, but 100\% RDN from leaf litter improves soil properties.

\section{Introduction}

Rice (Oryza sativa L.) is one of the most important cereal crops and Asia is considered as 'Rice bowl' of the world, occupying $90 \%$ area of world. Further, India is second largest rice growing country in the world. The rice production of our country reached to record of 106.19 million tonnes in the year 2013-2014 with $2225 \mathrm{~kg} /$ ha productivity (Anon., 2015). Vermicomposting can convert good quality manure from decomposable organic matter. Since, sericulture sector produces huge amount of unutilized waste including larval excreta, leaf litter, dead larvae, moth and cocoons (Das et al., 2003). In vermicomposting earthworms along with microorganisms mineralize, release and mobilize nutrients ( $\mathrm{N}, \mathrm{P}$ and $\mathrm{K}$ ) to convert the soil into quality compost (Mamata et al., 2010). Furthermore, in presence of organic source of nutrients increases available NPK 
uptake and rice grain yield (Ritamoni et al., 1999). Terminalia arjuna is distributed in scattered farm bunds looking to the importance of multipurpose uses especially for cultural and economical conception. Timber is locally multiple used like carts, agricultural implements, boat building, house building, plywood etc. It is one of the major tannin yielding trees and by decomposition of tree leaf litter is an integral and significant part of biochemical nutrient cycling and food webs of floodplain Agroforestry systems. In decomposition process, leaf litter nutrients are converted into available form for uptake by vegetation (Mitch and Gosselink, 1993). Moreover, the effect of different vegetations to enrich nutrient status depends on various factors such as the leaf chemistry, behavior of nutrient, nature of soil, organic matter accumulation, microbial activity and quantity of nutrient bearing minerals (Gedda, 2003). Moreover, the leaf is also a good source of wild tasar silk forage. Therefore, the present study is designed to know the nature and possibility of recurrent nutrient supply to the low laying agricultural field with the objective on impact of arjuna leaf litter and hosted tasar silkworm excreta on quality of paddy and soil properties.

\section{Materials and Methods}

The pot experiment was carried out during Kharif season of the year 2016 in polyhouse at Department of Natural Resource Management (Figure 1), ASPEE College of Horticulture and Forestry, Navsari Agricultural University, Navsari, Gujarat, India. Geographically, Navsari is located at $20.95^{\circ} \mathrm{N}$ latitude and $72.93^{\circ} \mathrm{E}$. It has an elevation of $9 \mathrm{M}$ above mean sea level. For pot experiment required soil from paddy grown farm and dry leaf litter and tasar silkworm excreta collected from the surface layer below the boundary plantation of $T$. arjuna in agriculture field and made into powder by the electric grinder and it was used during experiment as a fertilizer. Before the application of fertilizer the leaf litter $(0.504 \%$ $\mathrm{N})$ and excreta $(1.12 \% \mathrm{~N})$ and $\mathrm{N}$ was analyzed using Wet digestion (Chromic acid) method (Trivedi et al., 1999). Collected soil texture was black cotton with initial and after harvest of paddy soil available nitrogen (177 ppm), $\mathrm{P}_{2} \mathrm{O}_{5}$ (38.9 ppm), $\mathrm{K}_{2} \mathrm{O}$ (210.3 ppm), Organic carbon $(0.78 \%)$, EC $\left(0.36 \mathrm{dSm}^{-1}\right), \mathrm{pH}$ (7.91), Bulk density (1.46 $\left.\mathrm{g} \mathrm{cc}^{-1}\right)$ and Porosity $(44.7 \%)$ analyzed in the laboratory.

The experiment was laid out in Completely Randomized Design with four repetitions and nine treatments namely; $\mathrm{T}_{1}$ - Control (Without fertilizer), $\mathrm{T}_{2}-100 \%$ RDF (Recommended Dose of Fertilizer) through inorganic fertilizers, $\mathrm{T}_{3}-75 \%$ RDN (Recommended Dose of Nitrogen) through inorganic fertilizer $+25 \%$ RDN from arjuna hosted tasar silkworm excreta, $\mathrm{T}_{4}-50 \%$ RDN through inorganic fertilizer $+50 \%$ RDN from arjuna hosted tasar silkworm excreta, $\mathrm{T}_{5}-75 \% \mathrm{RDN}$ through inorganic fertilizer $+25 \%$ RDN from leaf litter of arjuna, $\mathrm{T}_{6}-75 \% \mathrm{RDN}$ through inorganic fertilizer $+25 \%$ RDN from leaf litter of arjuna, $\mathrm{T}_{7}-50 \%$ RDN through inorganic fertilizer $+25 \%$ RDN from arjuna hosted tasar silkworm excreta $+25 \%$ RDN from leaf litter of arjuna, $\mathrm{T}_{8}-100 \% \mathrm{RDN}$ from arjuna hosted tasar silkworm excreta, $\mathrm{T}_{9}$ - $100 \%$ RDN from leaf litter of arjuna. The recommended dose of N, P and K @ 100-30$00 \mathrm{mg} \mathrm{kg}^{-1}$ to paddy crop under pot trial was applied through leaf litter, tasar silkworm tasar excreta, Urea and Single Super Phosphate.

Application of recommended dose of $\mathrm{N}$ was done with three splits@ 40-40-20 kg N in the aqueous form of Urea, powdered form of leaf litter and tasar silkworm at 30 days interval.

The $\mathrm{P}$ was applied as basal dose at the time of transplanting. The 12 days old rice seedlings were transplanted in pot during first week of August 2016 and harvested in the second 
week of November 2016. Plant and soil sample were collected randomly from each pot and analyzed its properties in the laboratory by using standard methods (Trivedi et al., 1999; Jackson, 1973; Black, 1965; Subbiah and Asija, 1956; Singh et al., 2005).

The obtained data were statistically analyzed and compared by using CD test at 5\% of probability. The analysis of variance was worked out with the help of "DOC" data analysis software developed by Statistical Department, N.M. College of Agriculture, NAU, Navsari, Gujarat.

\section{Results and Discussion}

The results and discussion on quality of paddy and soil properties from the experiment are presented in the subsequent headings.

\section{Quality parameter}

\section{Nitrogen content $(\%)$}

Nitrogen content is one of the most important parameter for quality of crop.

The results pertaining to nitrogen content (\%) in grain and straw of paddy as influenced by different treatments are presented in Figure 2. Here, nitrogen content $(1.78 \%)$ was recorded significantly higher in grain and straw (1.18 $\%$ ) with $\mathrm{T}_{4}$ treatment which was at par with $\mathrm{T}_{3}, \mathrm{~T}_{5}, \mathrm{~T}_{6}, \mathrm{~T}_{7}, \mathrm{~T}_{8}$ and $\mathrm{T}_{9}$ treatments. It may be due to plants grown with the use of chemical fertilizers (RDF) contains less $\mathrm{N}$ in grains and straw as compared to its combination with organic fertilizers and alone use of organic fertilizers. The result was supported by Heenkende and Parama (2010) study where the combined application of chemical fertilizer (NPK) and municipal waste compost increased the $\mathrm{N}$ content in rice compared to the application of chemical fertilizers alone.

\section{Nitrogen uptake $\left(\mathrm{g} \mathrm{pot}^{-1}\right)$}

The results pertaining to nitrogen uptake ( $\mathrm{g}$ pot $^{-1}$ ) through grain and straw of paddy as influenced by different treatment are presented in Figure 2. The results indicated the significantly higher nitrogen uptake (1.18 $\mathrm{g} \mathrm{pot}^{-1}$ ) by grain in both $\mathrm{T}_{3}$ and $\mathrm{T}_{4}$ treatment. While in case of nitrogen uptake through straw (0.86 $\left.\mathrm{g} \mathrm{pot}^{-1}\right)$ was found significantly higher in $\mathrm{T}_{3}$ treatment which was at par with $\mathrm{T}_{2}$ and $\mathrm{T}_{4}$ treatments. It may be due to higher values of various yield attributes as well as relatively higher $\mathrm{N}$ content obtained in this treatment. The result was supported by Jana and Ghosh (1996) who shown that the application of $75 \%$ of RDF with $25 \% \mathrm{~N}$ from FYM gave the highest uptake of $\mathrm{N}, \mathrm{P}$ and $\mathrm{K}$ by paddy crop. Ritamoni et al. (1999) stated that the significant increase in the available NPK uptake of plant and grain yield by organic sources of nutrients in rice. Further, the nitrogen uptake by grain and straw of paddy was recorded lower in control.

\section{Protein content (\%) and yield}

The obtained results of protein content (\%) and protein yield $\left(\mathrm{g} \operatorname{pot}^{-1}\right)$ of paddy are presented in Figure 3. The study shows that the Protein content observed significantly higher in grain with $\mathrm{T}_{4}$ treatment which was at par with $\mathrm{T}_{3}, \mathrm{~T}_{5}, \mathrm{~T}_{6}, \mathrm{~T}_{7}, \mathrm{~T}_{8}$ and $\mathrm{T}_{9}$ treatments respectively. It may due to the growth of paddy with the provision of chemical fertilizers (RDF) alone produced grains having lesser protein contain as compared to its combination with organic fertilizers and use of organic fertilizers alone.

The significantly higher protein yield $(7.35 \mathrm{~g}$ pot $^{-1}$ ) was recorded same in both $T_{3}$ and $T_{4}$ treatment it might be higher grain yield and protein content in these treatment same therefore increase protein yield. Similarly, Patil et al., (2000) observed that increase in 
the level of fish manure also increased the protein content of paddy grain.

Again, Ram et al., (2000) demonstrated that quality of the rice grain in respect to protein content improved significantly with the integrated use of organic fertilizer with nitrogen as a chemical fertilizer. However protein content and yield was recorded significantly lower in control as compared to other treatments might be lack of nutrient and lower production in this treatment.

\section{Soil properties}

In order to assess the effect of different treatments on soil properties and available nutrients status of soil after paddy harvested treatment wise random soil samples were collected and analyzed for pertinent properties. The results thus obtained are presented in Table 1 here with following subheads.

\section{Chemical properties}

Significant effect on changes in chemical properties viz., $\mathrm{pH}$ and EC were observed in different treatments. The significantly the lower soil $\mathrm{pH}$ was recorded (7.72) with treatment $\mathrm{T}_{9}$ it may be due to the fact that the acidic nature of leaf litter extractive of $T$. arjuna might have decreased the soil $\mathrm{pH}$. However, initial soil $\mathrm{pH}$ was found improved marginally with different treatments over the control.

The effect of different treatment was found to be non-significant on EC of soil after harvest of paddy plant. It may be due to the quality of water. The results were supported by Singh et al. (2011) they observed slight decrease in the $\mathrm{pH}$ of soil with vegetated area, whereas no appreciable change in EC was observed.

\section{Soil fertility}

The results shows that the significantly maximum SOC (1.09\%) and K2O (243.3 ppm) was recorded in $100 \%$ RDN from leaf litter of arjuna $\left(\mathrm{T}_{9}\right)$ treatment (Table 1). The lowest SOC was recorded with control and the lowest $\mathrm{K}_{2} \mathrm{O}$ was recorded in chemical fertilizer treatment. Lousier and Parkinson (1976) emphasized that leaf litter is the most important source of energy and organic matter transferred from the tree canopy to decomposer organisms of the soil surface.

Similarly, Das et al., (2010) observed that incorporation of tree biomass (leaves and twigs) significantly improved the stock of soil available N, P and soil OC content as compared to control. The experimental results recorded significantly higher soil available $\mathrm{N}$ $(170.3 \mathrm{ppm})$ with $75 \%$ RDN through inorganic fertilizer combined with $25 \%$ RDN from arjuna hosted tasar silkworm excreta treatment $\left(\mathrm{T}_{3}\right)$ which was at par with $\mathrm{T}_{4}, \mathrm{~T}_{5}$ and $\mathrm{T}_{7}$, whereas, the lowest value was recorded in control $\left(\mathrm{T}_{1}\right)$. It may be due to the application of chemical fertilizer combined with organic fertilizer (either leaf litter or tasar silkworm excreta) which have higher amount of stored $\mathrm{N}$ in soil after harvest of paddy as compared to chemical fertilizer or leaf litter alone.

The highest soil $\mathrm{P}_{2} \mathrm{O}_{5}$ was recorded with $\mathrm{T}_{8}$ which was at par with $\mathrm{T}_{4}, \mathrm{~T}_{6}, \mathrm{~T}_{7}$ and $\mathrm{T}_{9}$ and lowest value of the same was recorded in control. This may be due to the application of initial $\mathrm{P}_{2} \mathrm{O}_{5}$ does equally in all treatment except control and released of $\mathrm{P}_{2} \mathrm{O}_{5}$ from organic material which increased the status of soil $\mathrm{P}_{2} \mathrm{O}_{5}$. The results was in line with Kenjale et al. (1994) who observed that available $\mathrm{N}$, $\mathrm{P}_{2} \mathrm{O}_{5}, \mathrm{~K}_{2} \mathrm{O}$ and exchangeable $\mathrm{Ca}$ and $\mathrm{Mg}$ were significantly higher in soil mixed with leaf litter than in barren soil. 
Table.1 Effect of different treatments on soil $\mathrm{pH}, \mathrm{EC}\left(\mathrm{dSm}^{-1}\right)$, SOC (\%), available $\mathrm{N}(\mathrm{ppm}), \mathrm{P}_{2} \mathrm{O}_{5}$ (ppm), $\mathrm{K}_{2} \mathrm{O}(\mathrm{ppm})$, bulk density $\left(\mathrm{g} \mathrm{cc}^{-1}\right)$ and porosity (\%) of soil after paddy harvest

\begin{tabular}{|c|c|c|c|c|c|c|c|c|c|c|}
\hline \multirow{2}{*}{\multicolumn{3}{|c|}{ Treatments }} & \multirow[t]{2}{*}{ pH } & \multirow[t]{2}{*}{$\begin{array}{c}\mathrm{EC} \\
\left(\mathrm{dSm}^{-1}\right)\end{array}$} & \multirow[t]{2}{*}{$\begin{array}{l}\text { SOC } \\
(\%)\end{array}$} & \multicolumn{3}{|c|}{$\begin{array}{l}\text { Available nutrients } \\
\text { (ppm) }\end{array}$} & \multirow{2}{*}{$\begin{array}{l}\text { Bulk } \\
\text { density } \\
\left(\mathrm{g} \mathrm{cc}^{-1}\right)\end{array}$} & \multirow[t]{2}{*}{$\begin{array}{l}\text { Porosity } \\
\qquad(\%)\end{array}$} \\
\hline & & & & & & $\mathbf{N}$ & $\mathbf{P}_{2} \mathbf{O}_{5}$ & $\mathrm{~K}_{2} \mathrm{O}$ & & \\
\hline \multicolumn{11}{|c|}{ Before experimented soil parameters } \\
\hline \multicolumn{3}{|c|}{ Initial soil } & 7.91 & 0.36 & 0.78 & 117.0 & 38.9 & 210.3 & 1.46 & 44.7 \\
\hline \multicolumn{11}{|c|}{ After experimented soil parameters } \\
\hline $\mathbf{T}_{1}$ & : & Control (no fertilizers) & 7.98 & 0.49 & 0.80 & 105.3 & 37.3 & 196.3 & 1.45 & 45.4 \\
\hline $\mathbf{T}_{2}$ & : & $\begin{array}{l}100 \% \text { RDF through } \\
\text { inorganic fertilizers }\end{array}$ & 7.95 & 0.50 & 0.83 & 158.1 & 40.1 & 166.1 & 1.43 & 46.2 \\
\hline $\mathbf{T}_{3}$ & $:$ & $\begin{array}{l}75 \% \text { RDN through } \\
\text { inorganic fertilizer }+25 \% \\
\text { RDN from arjuna hosted } \\
\text { tasar silkworm excreta }\end{array}$ & 7.87 & 0.50 & 0.88 & 170.3 & 42.5 & 168.8 & 1.42 & 46.2 \\
\hline $\mathbf{T}_{4}$ & $:$ & $\begin{array}{l}50 \% \text { RDN through } \\
\text { inorganic fertilizer }+50 \% \\
\text { RDN from arjuna hosted } \\
\text { tasar silkworm excreta }\end{array}$ & 7.87 & 0.51 & 0.91 & 169.1 & 44.8 & 172.4 & 1.40 & 47.3 \\
\hline $\mathbf{T}_{5}$ & $:$ & $\begin{array}{l}75 \% \text { RDN through } \\
\text { inorganic fertilizer }+25 \% \\
\text { RDN from leaf litter of } \\
\text { arjuna }\end{array}$ & 7.89 & 0.48 & 0.88 & 161.9 & 41.0 & 168.4 & 1.41 & 46.7 \\
\hline$T_{6}$ & : & $\begin{array}{l}50 \% \text { RDN through } \\
\text { inorganic fertilizer }+50 \% \\
\text { RDN from leaf litter of } \\
\text { arjuna }\end{array}$ & 7.78 & 0.50 & 0.96 & 140.3 & 43.5 & 173.2 & 1.40 & 47.0 \\
\hline $\mathbf{T}_{7}$ & : & $\begin{array}{l}50 \% \text { RDN through } \\
\text { inorganic fertilizer }+25 \% \\
\text { RDN from arjuna hosted } \\
\text { tasar silkworm excreta }+ \\
25 \% \text { RDN from leaf litter } \\
\text { of arjuna }\end{array}$ & 7.80 & 0.47 & 0.93 & 163.9 & 44.5 & 196.5 & 1.40 & 47.2 \\
\hline $\mathbf{T}_{8}$ & : & $\begin{array}{l}100 \% \text { RDN from arjuna } \\
\text { hosted tasar silkworm } \\
\text { excreta }\end{array}$ & 7.76 & 0.48 & 0.97 & 160.8 & 46.6 & 214.7 & 1.38 & 48.1 \\
\hline $\mathbf{T}_{9}$ & : & $\begin{array}{l}100 \% \text { RDN from leaf } \\
\text { litter of arjuna }\end{array}$ & 7.72 & 0.48 & 1.09 & 140.9 & 45.6 & 243.3 & 1.37 & 48.2 \\
\hline \multicolumn{3}{|c|}{ S. Em. \pm} & 0.05 & 0.01 & 0.02 & 3.06 & 1.38 & 3.89 & 0.01 & 0.42 \\
\hline \multicolumn{3}{|c|}{ C.D. @ $5 \%$} & 0.17 & NS & 0.06 & 8.88 & 4.01 & 11.29 & 0.03 & 1.22 \\
\hline \multicolumn{3}{|c|}{ C.V $(\%)$} & 1.20 & 5.60 & 4.84 & 4.02 & 6.45 & 4.12 & 1.58 & 1.79 \\
\hline
\end{tabular}


Fig.1 Overview of experiment in polyhouse at 90 days after transplanting of paddy

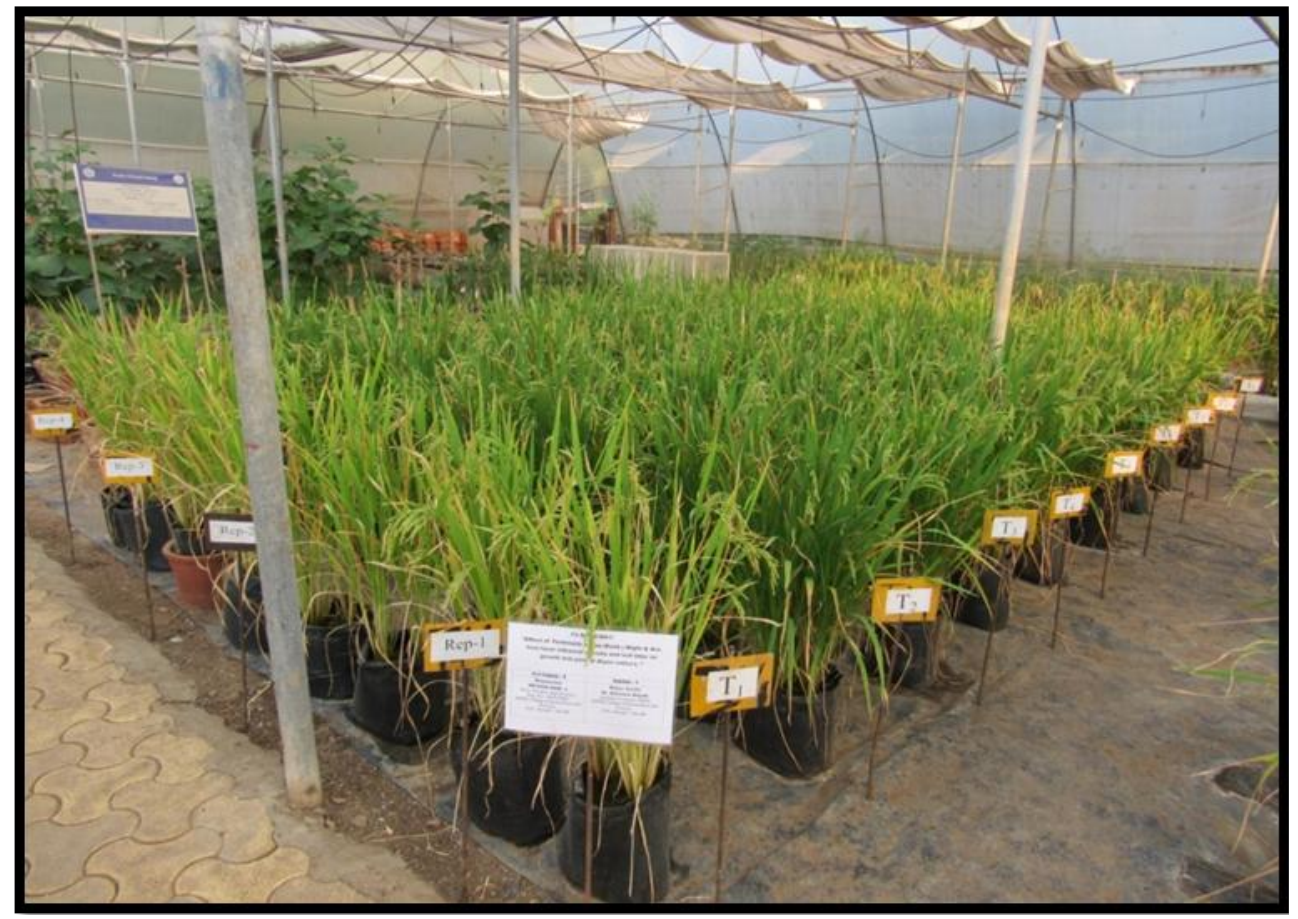

Fig.2 Effect of different treatments on nitrogen content (\%) and nitrogen uptake $\left(\mathrm{g} \operatorname{pot}^{-1}\right)$ of paddy

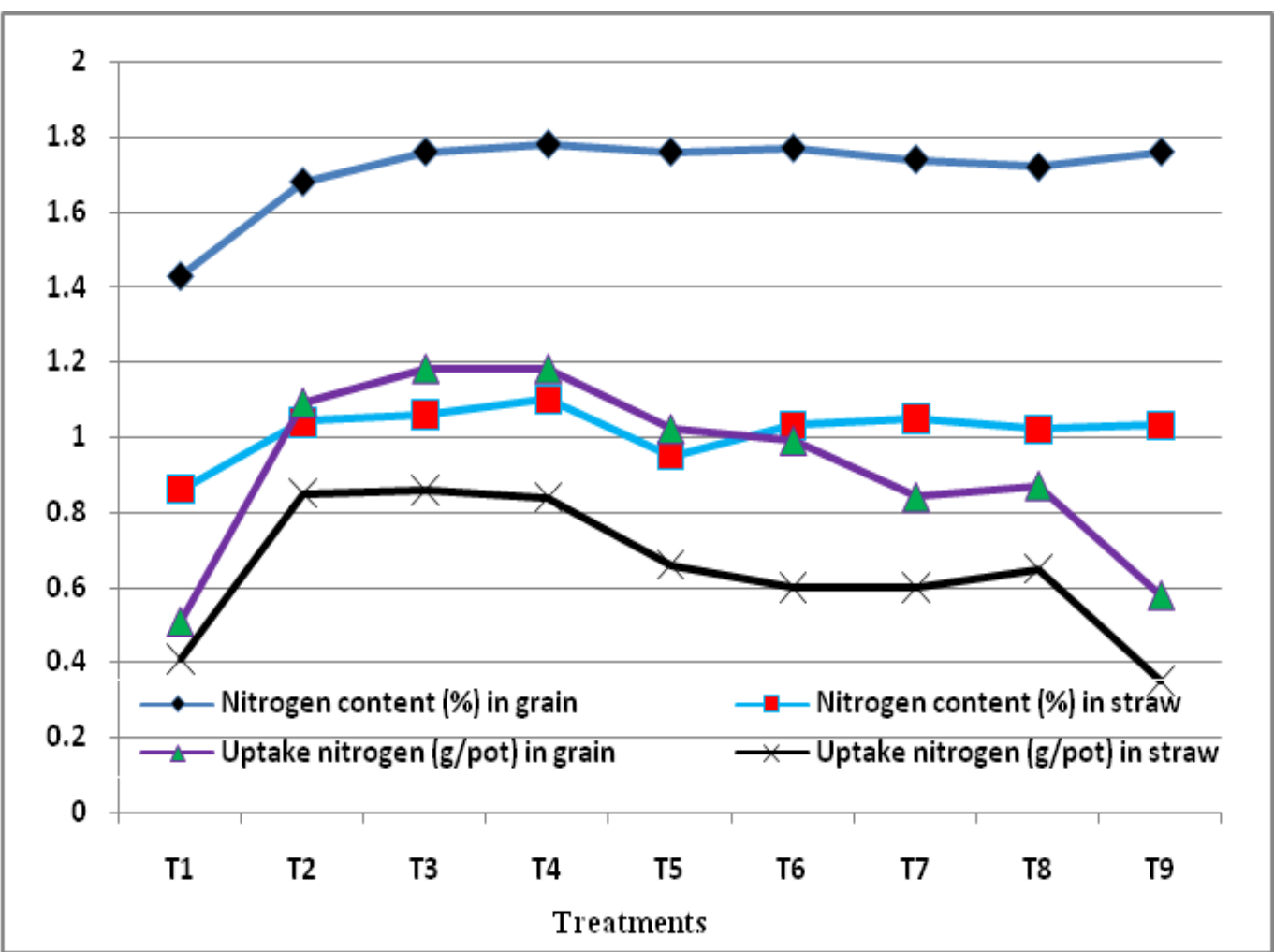


Fig.3 Effect of different treatments on protein content (\%) and protein yield $\left(\mathrm{g} \mathrm{pot}^{-1}\right)$ of paddy

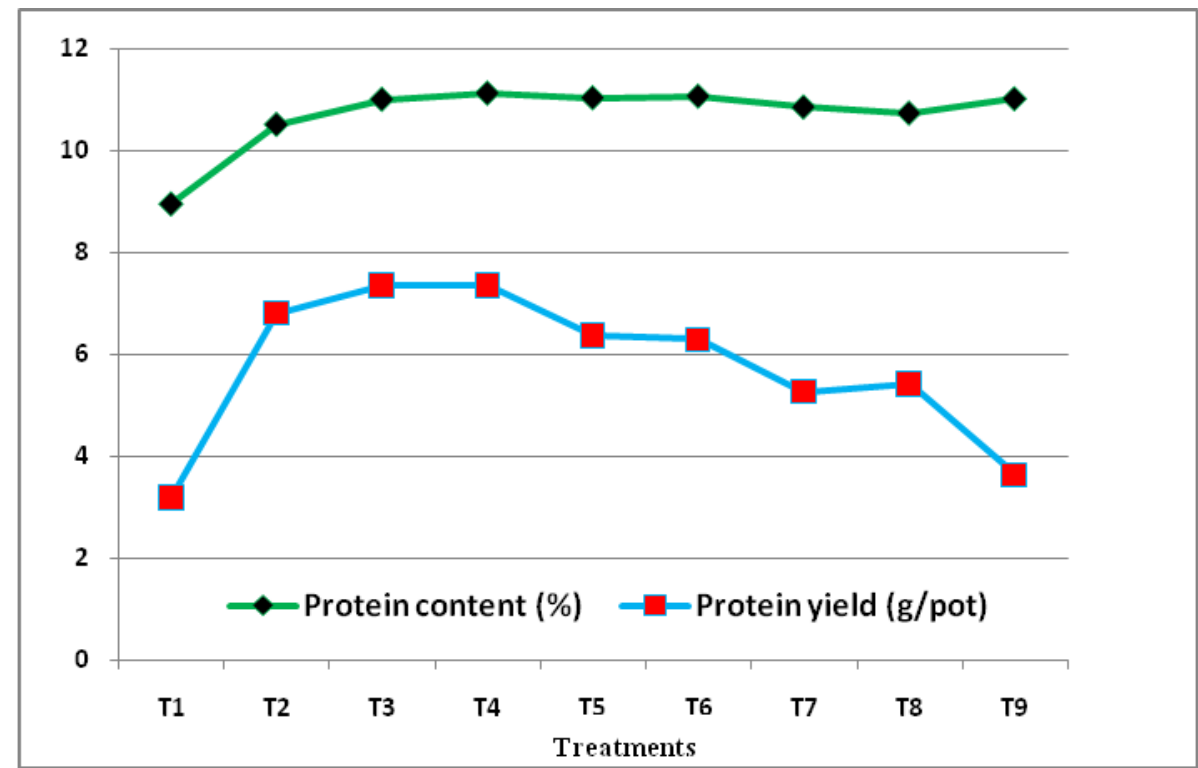

$\mathrm{T}_{1}$ - Control (Without fertilizer), $\mathrm{T}_{2}-100 \% \mathrm{RDF}$ (Recommended Dose of Fertilizer) through inorganic fertilizers, $\mathrm{T}_{3}$ $-75 \%$ RDN (Recommended Dose of Nitrogen) through inorganic fertilizer + 25\% RDN from arjuna hosted tasar silkworm excreta, $\mathrm{T}_{4}-50 \%$ RDN through inorganic fertilizer $+50 \%$ RDN from arjuna hosted tasar silkworm excreta, $\mathrm{T}_{5}-75 \% \mathrm{RDN}$ through inorganic fertilizer $+25 \% \mathrm{RDN}$ from leaf litter of arjuna, $\mathrm{T}_{6}-75 \% \mathrm{RDN}$ through inorganic fertilizer $+25 \%$ RDN from leaf litter of arjuna, $\mathrm{T}_{7}-50 \%$ RDN through inorganic fertilizer $+25 \%$ RDN from arjuna hosted tasar silkworm excreta $+25 \% \mathrm{RDN}$ from leaf litter of arjuna, $\mathrm{T}_{8}-100 \% \mathrm{RDN}$ from arjuna hosted tasar silkworm excreta, $\mathrm{T}_{9}-100 \% \mathrm{RDN}$ from leaf litter of arjuna.

\section{Physical properties}

The change in physical properties viz., bulk density and porosity was significantly influenced by all treatments after harvest of paddy of plant compared to initial. The bulk density $\left(1.37 \mathrm{~g} \mathrm{cc}^{-1}\right)$ of soil significantly decrease after harvest of paddy with the $\mathrm{T}_{9}$ treatment which was at par with treatments $\mathrm{T}_{4}, \mathrm{~T}_{6}, \mathrm{~T}_{7}$ and $\mathrm{T}_{8}$ and also porosity of soil significantly increase in same treatment it may be due to add leaf litter because it has high organic material. The minimum porosity of soil was reported under control. The result was supported by Singh et al. (2011) that the increase in the porosity and water-holding capacity and decrease in the bulk density (of subsurface soils) in the sites with plantations were marginal, when compared to open sites.

In conclusion, from the present study, it was recorded that the organic treatments (Leaf litter, excreta or both combined) always gave the improved quality of paddy crop and also increase soil fertility status than inorganic treatments. On the other hand, combined application of 50\% RDN through inorganic fertilizer $+50 \%$ RDN from arjuna hosted tasar silkworm excreta treatment increase quality of paddy crop in present study.

Further, the application of $100 \%$ RDN from leaf litter of arjuna treatment improved various soil parameter (Soil fertility, Chemical \& Physical properties). Leaf litter supplies essential nutrients in soil considering important source of soil productivity and ecosystem health. So, if we can utilize leaf litter and tasar excreta as a source of organic matter for paddy cultivation; one can reduce the considerable amount of chemical fertilizers. 


\section{Acknowledgments}

The authors are grateful to Dean and Principal, ASPEE College of Horticulture and Forestry, Navsari Agricultural University, Navsari for providing facility for carry out this experiment.

\section{References}

Anonymous (2015). Annual report 20142015, Department of Agriculture and Co-operation, Ministry of Agriculture, Government of India Krishi Bhawan, New Delhi-110 001 March, 2015.

Black, C. A. (1965). Methods of soil analysis part I and II. American Society of Agronomy, Inc. Pub. Madlson. Wilsconsin, USA.

Das, A., Tomar, J. M. S., Ramesh, T., Munda, G. C., Ghosh, P. K. and Patel, D. P. (2010). Productivity and economic of lowland rice as influenced by incorporation of $\mathrm{N}$-fixing tree biomass in mid-altitude subtropical Meghalaya, North East India. Nutr. Cycl. Agroecosysts, 80: 9-19.

Das, P. K., Bhogesha, K., Rajanna, L. and Dandin, S. B. (2003). Vermiculture as a means of seri cultural waste management technology an eco-friendly approach. Proc. Nat. Symp. Bioresources, Biotech and Bioenterprise, pp. 398-402.

Gedda A E. (2003). 'Rangeland evaluation in relation to Pastrolists perceptions in the Middle Awash Valley of Ethiopia', Ph D thesis, 297 pp. University of the Free State, Bloemfontein, South Africa.

Heenkende, A. P. and Parama, V. R. R. (2010). Effect of silkworm pupae compost on soil $\mathrm{N}$ mineralization, nutrient uptake, crop yield and plant nutrient contents of French Bean (Phaseolus vulgaris L.). Trop. Agric. Res., 21(4): 391-397.
Jackson, M. L. (1973) In: Soil Chemical Analysis, Prentice Hall of India, Pvt. Ltd., New Delhi.

Jana, M. K. and Ghosh, B. C. (1996). Integrated nutrient management of rice (Oryza sativa) - rice crop sequence. Indian J. Agron., 41(2): 183-187.

Kenjale, R. Y., Chavan, K. N. and Chavan, A. S. (1994). Recycling of nutrient elements by some forest tree species of Konkan in Maharashtra. II-Leaf litter decomposition and release of nutrient in lateritic soil of Konkan. Van Vigyan., 32(1/2): 7-14.

Lousier, J. D. and Parkinson, D. (1976). Litter decomposition in a cool temperature deciduous forest. Canadian J. Bot., 54: 419-436.

Mamata Pandey; Rao, T. V. and Satapathy, S. K. (2010). Nutrients and exoenzymes in vermicompost of eri and tasar culture waste. An Int. Quar. J. Lif. Sci., 1: 211216.

Mitch, W.J. and Gosselink, J.G. (1993). Wetlands $2^{\text {nd }}$ ed. Van. Nosirand Reinhold, New York. pp. 205-240.

Patil, S. H., Talashilkar, S. C. and Mehta, V. (2000). Integrated nutrient management using fish meal and fertilizer for rice (Oryza sativa). Indian J. Agril. Sci., 70(1): 31-33.

Ram, S., Chauhan, R. P. S., Singh, B. B. and Singh, V. (2000). Integrated use of organic and fertilizer nitrogen in rice (Oryza sativa). Indian J. Agril. Sci., 70(2): 114-116.

Ritamoni, B., Haridev, T., Talukdar, N. C., Baruah, R. and Talukdar, H. (1999). Soil chemical properties as influenced by the application of FYM. Int. J. Tropic. Agric., 17(1-4): 153-158.

Singh, D., Chhonkar, P. K. and Dwivedi, B. S. (2005) In: Manual on soil, plant and water analysis. Westville Publishing House, New Delhi, Pp: 84-88. 
Singh, I. S., Awasthi, O. P., Singh, R. S., More, T. A. and Meena, S.R. (2011). Changes in soil properties under tree species. Indian J. Agric. Sci., 82(2): 146-51.

Subbiah, B. V. and Asija, G. L. (1956) A rapid procedure for the estimation of available $\mathrm{N}$ in soils. Current Science, 27: 259-260.

Trivedi, B. S., Patel, G. G., Desai, R. M. and Padhiyar, G. M. (1999) Comparison of Kjeldahl's and Chromic acid methods of nitrogen determination. Gujarat Agri. Uni. Res. J., 25(91): 9-14.

\section{How to cite this article:}

Mevada, R.J., Dileswar Nayak and Patel, D.P. 2018. Impact of Terminalia arjuna (Roxb.) Leaf Litter and Hosted Tasar Silkworm Excreta on Soil Properties and Quality of Paddy. Int.J.Curr.Microbiol.App.Sci. 7(05): 3781-3789. doi: https://doi.org/10.20546/ijcmas.2018.705.439 